\title{
The endothelial progenitor cell dysfunction in hypertension: the diagnostic and predictive values
}

\author{
Alexander E Berezin \\ Department of Internal Medicine, State Medical University, Zaporozhye 69035, Ukraine. \\ Correspondence to: Prof. Alexander E Berezin, Department of Internal Medicine, State Medical University, Mayakovsky av., \\ Zaporozhye 69035, Ukraine.E-mail: aeberezin@gmail.com; dr_berezin@mail.ru \\ How to cite this article: Berezin AE. The endothelial progenitor cell dysfunction in hypertension: the diagnostic and predictive \\ values. Vessel Plus 2018;2:22. http://dx.doi.org/10.20517/2574-1209.2018.23
}

Received: 28 Apr 2018 First Decision: 23 Jul 2018 Revised: 25 Jul 2018 Accepted: 2 Aug 2018 Published: 13 Sep 2018

Science Editor: Alexander D. Verin Copy Editor: Huan-Liang Wu Production Editor: Zhong-Yu Guo

\begin{abstract}
Hypertension remains a leading risk factor of cardiovascular (CV) events and disease in the general population. The prevalence of hypertension is present in developed and developing countries and according to various assessments may fluctuate between $30 \%$ to $90 \%$ with considerable regional differences. Hypertension influences CV risk and mortality rate through target organ damages that affect vasculature particularly endothelium. Endothelial dysfunction is an independent risk factor of CV complications. Recent studies have shown that a decreased number and altered function of circulating endothelial progenitor cells (EPCs) may be a powerful marker of endothelial dysfunction with possible predictive value. The aim of this review is to update the current evidence of the role of endothelial progenitor cell dysfunction in impaired vascular reparation and $\mathrm{CV}$ risk in hypertension. The review discusses the interrelation between EPC dysfunction and traditional CV risk factors, such as hypertension, dyslipidemia, obesity, prediabetes/diabetes mellitus. It has been speculated that EPC dysfunction could appear prior to hypertension and represents an appropriate hypertensive phenotype with exaggerated CV risk. However, the predictive value of EPC dysfunction in hypertensive patients is not established and requires to be investigated in large clinical controlled trials.
\end{abstract}

Keywords: Hypertension, endothelial dysfunction, endothelial progenitor cells, vascular reparation, biomarkers

\section{INTRODUCTION}

Hypertension is now recognized as an established powerful risk factor for cardiovascular disease (CVD) that is a primary cause of mortality and disability worldwide ${ }^{[1]}$. The prevalence of hypertension relates closely to age, sex, urban/rural location, lowered income in certain countries, affordability of insurance, type of nutrition, and comorbidities, such as diabetes mellitus, obesity, and chronic kidney disease ${ }^{[2,3]}$. The prevalence of the disease in developing and developed countries varies and fluctuates from 30\% to $90 \%$ confirming

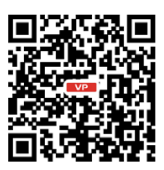


considerable regional differences in the prevalence of hypertension ${ }^{[4,5]}$. Moreover, there is evidence that up to $90 \%$ of all hypertensive patients have uncontrolled blood pressure (BP) determined as $>140 \mathrm{mmHg}$ and > $90 \mathrm{mmHg}$ for office systolic and diastolic BP respectively ${ }^{[5,6]}$. Recent observational and clinical studies have shown that target organ damages were more frequently detected in uncontrolled hypertensive individuals and resistant hypertensive patients than those who had fully controlled hypertension ${ }^{[5,7]}$. Nevertheless, it was found that the endothelial dysfunction may be a result of direct vasculature damage due to the effect of cardiovascular $(\mathrm{CV})$ risk factors and the natural evolution of hypertension ${ }^{[7,8]}$. Additionally, endothelial dysfunction is strongly associated with not only a very high CV risk profile, but a higher rate of CV events in hypertensive individuals ${ }^{[8]}$. Although endothelial dysfunction emerges as a primary cause of essential hypertension and its evolution understanding the whole components involving in the pathophysiology of regulation of vascular structure and function become of great importance for the prediction of target organ damage and risk stratification ${ }^{[9]}$. The investigation of clinical significance of the role of endothelial dysfunction in developing and progression of essential hypertension could open novel perspectives for targeting the treatment of hypertension.

The pathophysiological mechanisms of endothelial dysfunction development involve several factors contributing to various causes of loss of normal vascular function and structure. The experimental models of essential hypertension have confirmed that genetic/epigenetic factors interacting with traditional (smoking, dyslipidemia, insulin resistance, diabetes mellitus) and specific (hyperuricemia, vitamin D deficiency, elevated homocysteine levels, inflammation, oxidative stress, hypercoagulation) CV risk factors and surrounding environment may regulate vascular reparation through synthetiz ing and release of various spectra of vasoactive substances including nitric oxide (NO), involving cell mechanisms and attenuation of synthesis of pro-inflammatory cytokines, chemokines, and reactive oxygen species $(\mathrm{ROS})^{[10-14]}$. Consequently, vascular resident cells and circulatig progenitor cells with different origin and phenotypes (mononuclear and endothelial progenitor cells) may play a pivotal role in vascular repair, improving vascular integrity and function ${ }^{[15]}$. Finally, the imbalance between vasculature damage and vascular reparation capability could be considered as an independent factor contributing to endothelial function and vasculature structure that are central players in vascular tone regulation and target organ damage prevention ${ }^{[16-19]}$. The aim of this review is to update the current evidence of the role of endothelial progenitor cell dysfunction in impaired vascular reparation and CV risk in hypertension.

\section{DEFINITION OF ENDOTHELIAL PROGENITOR CELLS}

The pioneer work provided by Asahara et al. ${ }^{[20]}$ (1997) first reported about existing populations of circulating cells with impressive angiogenic capacities. Using animal models of ischemia the authors found sites of active angiogenesis with incorporation into its putative progenitor endothelial cells or angioblasts, which were further isolated from peripheral blood of animals and humans by magnetic bead selection on the basis of cell surface antigen expression ${ }^{[20,21]}$. In vitro these cells expanded and committed to form an endothelial lineage in colonies in culture, and in vivo after transplantation these cells have been incorporated into cores of active neovascularization demonstrating an ability to attenuate angiogenesis and vascular function through differentiation into mature microvascular endothelial cells ${ }^{[22,23]}$. It has been postulated that these cells called endothelial progenitor cells (EPCs) may origin from bone marrow stem cells and human umbilical cord blood and that they may mobilize and migrate from bone marrow, differentiate into mature endothelial cells and probably smooth muscle cells of vessels, as well as synthase and release a wide range of active molecules and growth factors [vascular endothelial growth factor (VEGF), fibroblast growth factor, granulocyte-macrophage colony-stimulating factor] that modulate vasculogenesis and improve vascular integrity ${ }^{[24,25]}$.

\section{DETERMINATION OF IMMUNE PHENOTYPES AND FUNCTIONALITIES OF EPCS}

Early attempts to verify the population of EPCs were based on determination of molecular characteristics especially when flow cytometry technique was being implemented. To improve the understanding in im- 
mune phenotypes of EPCs, a consensus on common strong endothelial markers was initiated, which are expressed on the surface of these precursors. The cells may express cell markers of endothelial cells and their precursors, such as CD31, CD144, KDR (CD309, VEGF receptor-2), and CD133, but in absence of CD45 ${ }^{[26,27]}$. The CD45(-) cells, which are detected and isolated based on single or combined expression of CD34, CD133 and $\mathrm{CD} 309$, were referred to as $\mathrm{EPCs}^{[26]}$. Three antigens, i.e., CD133, CD34, and $\mathrm{CD} 309$, are constitutively determined on the surfaces of EPCs, while after differentiation EPCs lose CD133 antigen and begin to be positively present on CD31, vascular endothelial cadherin, endothelial NO synthase (eNOS) and von Willebrand factor. However, EPCs expressed sufficient distinction in self-renewal ability that was determined using colony-forming method ${ }^{[28]}$. It has been speculated that a specific property may allow a more precise definition of EPCs, because the majority of antigens used as molecular markers were commonly shared with the various cells from hematopoietic lineage ${ }^{[29]}$. Indeed, some fractions of EPCs with high proliferating capacity could contain non-hematopoietic population of $\mathrm{CD} 45(-), \mathrm{CD} 31(+)$ cells with additional presentation CD117(+). Taken together, the combination of CD45(-), CD31(+), CD 133(+), CD34(+) and CD309(+) or von Willebrand factor $(+)$ probably allows for getting reliable purification of progenitor endothelial subsets from mononuclear cells with presentation of endothelial markers.

Depending on the ability to appear in fibronectin coated dish all EPCs were divided into early outgrowth (5-7 days after fibronectin plating) or late outgrowth endothelial cells (7-10 days after fibronectin plating). Interestingly, the late outgrowth precursors originated from peripheral blood mononuclea cells and ex vivo demonstrated immune phenotypes $\left(\mathrm{CD} 31^{+}, \mathrm{CD} 146^{+}, \mathrm{CD} 105^{+}\right.$, and $\left.\mathrm{CD} 309^{+}\right)$and functional properties suitable as mature endothelial cells. Indeed,two distinguished populations of late outgrowth progenitor cells based on differential expression of the cell surface marker CD34 have been identified. The population of EPCs with co-expression of CD34 antigen additionally to CD31(+), CD146(+), CD105(+), and CD309(+) exhibited higher proliferative capability to CD34(-) EPCs. Therefore, CD34(+) EPCs had reproduced tubes and colony shaping in the single-cell colony-formation investigation as well as they responded to angiogenic growth factors ${ }^{[28]}$. In contrast, CD34(-) cells had limited capability to reproduce colonies or even had none of these properties in vitro. There is evidence that the absence of CD34(+) EPCs in the colony leads to cultures collapsing within one or two passage and confirming a strong hierarchy in self-renewal of EPCs, which may be an extremely important functional feature of precursors ${ }^{[28]}$. Thus, late outgrowth precursors may differentiate into functionally mature endothelial cells and progenitor-like angiogenesis-promoting cells $\left(\mathrm{CD} 34^{+} \mathrm{EPCs}\right)^{[29]}$. In fact, the colonies are shaped by heterogeneous populations of EPCs that express different markers suitable for endothelial and monocyte lineage. Finally, CD34(+) EPCs mediate marginally to angiogenesis and neovascularization by differentiation, although they are potent triggers and powerful regulators of proinflammatory response and remodeling of vascular wall ${ }^{[29,30]}$. Other candidates for cell surface molecule markers and genes' signatures to a functional determination based surely on self-renewal hierarchy of EPCs are actively investigated. Thus, there are several populations of endothelial progenitors with different proliferative activity and angiopoetic capabilities that can represent markers of endothelial reparation/injury and endothelial dysfunction.

\section{THE MECHANISMS OF ANGIOPOETIC ACTIVITY OF EPCS}

Previous preclinical and clinical studies have shown that several factors, such as VEGF, stromal cellderived factor-1 (SDF-1) may enhance differentiation, proliferation, adhesion, and incorporation into endothelial cell monolayers of EPCs through VEGF/eNOS-related and chemokine SDF-1 Akt-related pathways ${ }^{[31-33]}$. Moreover, there is evidence that the blockade of VEGF or eNOS prevented all VEGF-induced and SDF-1alpha-induced effects toward EPCs including ischemia-induced proliferation, vasculogenesis and angiogenesis ${ }^{[33,34]}$. In this context, the transfer of genes (cdkn1c and il33) that are coding p57 and an endothelial cell cycle inhibitor may regulate self-renewal capacity of EPCs. Recent studies confirmed that increased expression of these target genes of Notch signaling play a pivotal role in regulation of cell cycling with EPCs and stem cells ${ }^{[35,36]}$. Thus, EPCs contribute their angiopoetic effect through direct differentiation into mature endothelial cells and probably into cells with other phenotypes like smooth muscle cells ${ }^{[37]}$. 
Additionally, there are data that confirmed that circulating EPCs originated from bone-marrow stem cells and peripheral mononuclear cells may directly contact to the injury sites of endothelium and influence them to induce local proliferation of residence cells, as well as promote auto- and paracrine effects. Indeed, acting as circulating EPCs enables to exhibit auto- and paracrine influences of hematopoietic cells including mononuclear cells, as well as local residence cells with high proliferative capacity ${ }^{[37-39]}$. In this way, EPCs release micro vesicles with regulatory proteins, peptides, micro-RNAs, growth factors (VEGF), and hormones (aldosterone) and secrete a wide spectrum of active molecules (E-selectin, P-selectin) directly into the circulation ${ }^{[40,41]}$. Both secretome and proteome of EPCs were recognized as central players in the reparation of the endothelial layer and restoring of vascular function ${ }^{[42]}$. Indeed, EPCs turn over mature endothelial cells and immediately become a target for inflammatory cytokines, factors of coagulation, hormones (catecholamines, aldosterone, angiotensin-II, endothelin-1), active molecules that have the ability to induce apoptosis. Apoptotic endothelial cells switch over to the secretion of micro vesicles to nanoparticles, which contain chromatin. Apoptotic-related nanoparticles are produced by mature endothelial cells and directly lead to injury of the endothelium and mediate inflammation and coagulation, but activated mature endothelial cells realize micro vesicles with angiopoetic properties that enhance vascular reparation and attenuate endothelial function ${ }^{[42,43]}$. Thus, EPCs with angiopoetic phenotypes may interact with vasculature in direct and indirect ways depending on the pre-existing ability of EPCs to proliferation, differentiation and survival as well as the spectrum of co-regulatory factors, which mainly alter maturation and commitment of stem cells/progenitor precursors and impair EPC mobilization.

\section{THE EPCS DYSFUNCTION: RELATION TO CARDIOVASCULAR RISK FACTORS}

EPC dysfunction was described as a phenomenon strongly associated with decreased number and/or weak function of circulating precursors ${ }^{[42]}$. Deficiency of circulating number of EPCs and weak function of them are found in senescence, atherosclerosis, stable coronary artery disease, myocardial infarction/ acute coronary syndrome, heart failure, atrial fibrillation/flutter, chronic kidney disease, morbid obesity, diabetes mellitus, hyperthyroidism, insulin resistance ${ }^{[15,19]}$. Recent clinical studies have shown that EPCs strongly related to metabolic comorbidities (hyperuricemia, dyslipidemia, hyperglycemia) and appeared to resultin epigenetic modification of these cells ${ }^{[43-46]}$. Although simple count of circulating number of EPCs is not superior to the assay of colony-shaping ability of EPCs in the context of association with CV mortality rate, the number of circulating EPC has shown to be negatively correlated with CV risk factors and vascular function and to predict $\mathrm{CV}$ disease/events independently of both conventional and non-traditional CV risk factors ${ }^{[47-49]}$. Moreover, the loss of the ability to release micro vesicles from EPCs can be a mechanism of worsening of glomerular function due to microvascular inflammation and endothelial dysfunction in chronic kidney disease ${ }^{[50]}$.

There is a suggestion that EPC dysfunction may appear prior to CVD without close association with CV risk factors, although conflicting data were obtained by numerous investigators. It has been found that the metabolic memory phenomenon in diabetics and pre-diabetics could be a result of EPC dysfunction ${ }^{[44]}$. Variability of glycated hemoglobin levels at early stages of diabetes mellitus development and insulin resistance are well established factors contributing to lowered numbers and poor function of circulating $\mathrm{EPCs}^{[19,40,51]}$. In contrast, there are studies that reported unchanged or increased numbers of circulating EPCs in diabetics, in patients with increased serum uric acid and in individuals with hypertriglyceridemia in comparison with healthy age-matched volunteers ${ }^{[52-54]}$. Previous studies reported that in healthy individuals the gender had no essential effect on the number of EPCs and that there was no effect on the number of EPCs factors such as: smoking, physical activity and alcohol consumption ${ }^{[5]}$. Kulwas et al ${ }^{[56]}$ reported that an increased number of circulating EPCs was found in patients with diabetic foot syndrome (DFS), but in diabetics without foot complications and healthy volunteers, the circulating number of EPCs was similar. In contrast, subjects with DFS, even with healed ulceration, had fewer EPCs and more CD45-CD29(+)CD90(+) mesenchymal stem cells when compared with the T2DM without $\mathrm{DFS}^{[57]}$. However, numerous metabolic 
risk factors and diseases including diabetes mellitus themselves did not affect bone-marrow mobilization of precursors, but they altered the EPC profile and decreased the circulating number of late outgrowth EPCs with high proliferative capability that sufficiently worsend the reparative ability of vasculature ${ }^{[54]}$. On the other hand, local tissue ischemia is thought to be the strongest inductor of EPC mobilization, angiogenesis and reparation, but data mentioned above did not confirm that several conditions, such as DFS, obligatory accompany intensive angiogenesis are associated with increased circulating number of angiogenic EPCs and high concentration of VEGF and fibroblast growth factor. Additionally, it has been found that decreased soluble receptors for VEGF due to inactivation of VEGF, may correspond to decrease in the number of EPCs in the circulation ${ }^{[56-58]}$. Although EPCs are crucial to vasculogenesis and angiogenesis during ischemic neovascularization the controversial findings regarding both number and function of EPCs in peripheral blood require to be explained in details. Probably, EPCs are under tight control of several epigenetic mechanisms, i.e., DNA methylation, DNA phosphorylation, micro-RNA-related translation, etc., which mediate a modification of EPC function, decrease the number of EPCs and suppress their survival. Moreover, it has been postulated that the worsening of EPCs function is attributed to the time period during which EPCs have been in contact with CV risk factors and epigenetic stimuli ${ }^{[59]}$. As a result, the ability of the vasculature to repair itself is dramatically lowered. All these facts explain that even newly differentiated mature endothelial cells from precursors did not completely restore vascular integrity and function. Finally, endothelial dysfunction tends to persist and damage target organs leading to increased CV risk.

The next controversies affect the fact of unpredictable changes of number of EPCs in the peripheral blood in acute situations, such as acute heart failure (AHF) or acute coronary syndrome (ACS), or cardiac/ vascular surgery procedures ${ }^{[60,61]}$. Some investigators reported that the number of circulating EPCs in AHF or ACS/myocardial infarction was increased, but on the other hand there were reports of a lowered or an unchanged number of EPCs in humans within hours or days after manifestation of the events ${ }^{[62-66]}$. Also, the number of urgently recruited bone-marrow precursors can be limited due to previous expenditures for tissue reparations, which occurred prior to $\mathrm{CV}$ events, i.e., traumas and infections. On the other hand, ischemia/ hypoxia, several spectra of pro-inflammatory cytokines [tumor necrosis factor-alpha, interleukin (IL)-2, IL-4, IL-6, C-reactive protein], chemokines (E selectin), active molecules (intercellular adhesion molecule-1), matrix metalloproteinases (MMPs) and ROS that accompany atherothrombotic states, AHF, and release due progression of them are established factors for mobilization, proliferation and differentiation of $\mathrm{EPC}^{[66-69]}$. These factors impair hypoxia inducible factor-1 alpha (HIF)/p-Akt/p-eNOS/MMP-9 signaling system in stem cells and circulating precursors that lead to delayed and reduced EPC mobilization from bonemarrow and probably from peripheral tissues ${ }^{[70,71]}$. The final result for changes of the number of circulating of EPCs depends on a balance between the ability of stimuli to immediately mobilize precursors from bonemarrow/tissues and the pool of putative precursor cells ${ }^{[72-74]}$. Interestingly, improved functions of EPCs in hypertensive patients can be attained with the implementation of renin-angiotensin system blockers, such as angiotensin-converting enzyme inhibitors, angiotensin-II receptor blockers, direct renin inhibitors, and probably mineralocorticoid antagonists acting via intracellular signaling mechanisms related to SDF-1/CXC chemokine receptor four (CXCR4) and Janus kinase-2/CXCR4 axis $^{[75-78]}$. Thus, EPC dysfunction is a novel pathophysiological mechanism underlying defective neovascularization and vascular/tissues reparation in CVD.

\section{THE DIAGNOSTIC AND PROGNOSTIC VALUES OF EPCS IN HYPERTENSION}

Endothelial dysfunction is expressed by an increase of the endothelin-1 level and decreased bioavailability of nitric oxide associated with altered pro-coagulative, pro-inflammatory, and pro-vasoconstrictive phenotypes, and it is an early event in CVD that frequently precedes CV complications ${ }^{[79]}$. It has been reported that EPC colony number was significantly and inversely correlated with systolic and diastolic BP in subjects with hypertension ${ }^{[78]}$. A lowered number of EPCs in circulation was found at an early stage and represents a reliable predictor of endothelial dysfunction as well as a marker of target organ damages ${ }^{[80-82]}$. Indeed, 
decreased EPC levels may contribute to the pathophysiology of albuminuria or proteinuria in hypertensive patients with nephropathy. In patients with essential hypertension with ECG evidence of left ventricular hypertrophy (LVH), the circulating levels of EPCs were lowered to those who did not have $\mathrm{LVH}^{[81]}$. In hypertensive individuals with end-stage renal disease, EPC number and function were significantly reduced and inversely associated with CV risk ${ }^{[82]}$. Moreover, the levels of EPCs in the peripheral blood of women with pregnancy-induced hypertension were significantly lower compared with those of control pregnant women with normal BP level ${ }^{[83]}$. Numerous investigators reported that a lowered number of EPC and an altered EPC function related strongly not only with brachial BP levels, but the increased central aortic systolic pressure, aortic augmentation index, and pulse wave velocity as a marker of arterial stiffness. It altered brachial artery flow-mediated dilatation as a marker of endothelial dysfunction and left ventricular (LV) twisting ${ }^{[77,84-87]}$. Additionally, patients with newly diagnosed essential hypertension had increased proportions of various CD34(+) populations of EPCs and CD34(+)VEGFR2(+) c-Kit(+) EPCs ${ }^{[88]}$. Moreover, CD34(+) EPCs seem to be influenced by angiotensin II and KLOTHO encoding gene polymorphism ${ }^{[8,89]}$. It has been suggested that the increased proportions of $\mathrm{CD} 34^{+}$EPCs in the circulation may be a compensatory mechanism for increased endothelial damage and microvasculature inflammation in hypertension ${ }^{[88]}$.

However, the predictive role of EPC dysfunction in hypertensive individuals remains controversial. Although there is a relation between both lowered level of circulating EPCs and weak EPC function in vitro and an increased CV risk, there is not quite enough evidence regarding independent prognostication of EPC dysfunction in the hypertensive population ${ }^{[90]}$. In contrast, in patients with established CAD, myocardial infarction, heart failure, cardiomyopathies, the EPC dysfunction was determined to be a predictor of fatal clinical outcomes ${ }^{[91,92]}$. In fact, EPC dysfunction associates with CV risk and frequently associates with a number of CV risk factors including hypertension, dyslipidemia, abdominal obesity, prediabetes/diabetes mellitus. Whether EPC dysfunction appears prior to hypertension or it shapes the hypertensive phenotype without corresponding to other CV risk factors is not fully clear ${ }^{\left[{ }^{3}\right]}$. In this context, the independent predictive value of EPC dysfunction in hypertensive patients requires to be investigated in details in large clinical controlled trials.

\section{CONCLUSION}

The altered endothelial function in hypertensive patients is strongly associated with a decreased number and a reduced function of EPCs and may be determined even at a pre-hypertensive stage of the evolution of the disease. There is much evidence that EPCs play a pivotal role in maintaining the vascular integrity and reparation preventing alteration of the endothelium and manifestation of endothelial dysfunction. The EPCs dysfunction is established independent of CV risk factors in the general population and in patients with known CV disease. In this context, a number of circulating EPCs can be recognized as potential diagnostic and prognostic biomarkers in hypertensive individuals, while there is not quite enough evidence from large clinical trials.

\section{DECLARATIONS}

\section{Authors' contributions}

Berezin AE solely responsible for the paper

\section{Availability of data and materials}

Not applicable.

\section{Financial support and sponsorship}

None. 


\section{Conflicts of interest}

The author declares that there are no conflicts of interest.

\section{Ethical approval and consent to participate}

Not applicable.

\section{Consent for publication}

Not applicable.

\section{Copyright}

(c) The Author(s) 2018.

\section{REFERENCES}

1. Diederichs C, Neuhauser H. Regional variations in hypertension prevalence and management in Germany: results from the German Health Interview and Examination Survey (DEGS1). J Hypertens 2014;32:1405-13.

2. de Burgos-Lunar C, Jiménez-García R, Salinero-Fort MA, Gómez-Campelo P, Gil A, Abánades-Herranz JC, Cárdenas-Valladolid J, del Cura-González I. Trends in hypertension prevalence, awareness, treatment and control in an adult type 2 diabetes Spanish population between 2003 and 2009. PLoS One 2014;9:e86713.

3. Pereira M, Lunet N, Azevedo A, Barros H. Differences in prevalence, awareness, treatment and control of hypertension between developing and developed countries. J Hypertens 2009;27:963-75

4. Basu S, Millett C. Social epidemiology of hypertension in middle-income countries: determinants of prevalence, diagnosis, treatment, and control in the WHO SAGE study. Hypertension 2013;62:18-26.

5. Brambilla G, Bombelli M, Seravalle G, Cifkova R, Laurent S, Narkiewicz K, Facchetti R, Redon J, Mancia G, Grassi G. Prevalence and clinical characteristics of patients with true resistant hypertension in central and Eastern Europe: data from the BP-CARE study. J Hypertens 2013;31:2018-24.

6. Egan BM, Zhao Y, Axon RN. US trends in prevalence, awareness, treatment, and control of hypertension, 1988-2008. JAMA 2010;303: 2043-50.

7. Gkaliagkousi E, Gavriilaki E, Triantafyllou A, Douma S. Clinical significance of endothelial dysfunction in essential hypertension. Curr Hypertens Rep 2015;17:85.

8. Bernatova I. Endothelial dysfunction in experimental models of arterial hypertension: cause or consequence? Biomed Res Int 2014;2014:598271.

9. Brandes RP. Endothelial dysfunction and hypertension. Hypertension 2014;64:924-8.

10. Dinh QN, Drummond GR, Sobey CG, Chrissobolis S. Roles of inflammation, oxidative stress, and vascular dysfunction in hypertension. Biomed Res Int 2014;2014:406960.

11. de Faria AP, Fontana V, Modolo R, Barbaro NR, Sabbatini AR, Pansani IF, Ferreira-Melo SE, Moreno H. Plasma 8-isoprostane levels are associated with endothelial dysfunction in resistant hypertension. Clin Chim Acta 2014;433:179-83.

12. Choi YJ, Yoon Y, Lee KY, Hien TT, Kang KW, Kim KC, Lee J, Lee MY, Lee SM, Kang DH, Lee BH. Uric acid induces endothelial dysfunction by vascular insulin resistance associated with the impairment of nitric oxide synthesis. FASEB J 2014;28:3197-204.

13. Wong WT, Tian XY, Huang Y. Endothelial dysfunction in diabetes and hypertension: cross talk in RAS, BMP4, and ROS-dependent COX-2-derived prostanoids. J Cardiovasc Pharmacol 2013;61:204-14.

14. Martynowicz H, Janus A, Nowacki D, Mazur G. The role of chemokines in hypertension. Adv Clin Exp Med 2014;23:319-25.

15. Berezin AE. Preconditioned endothelial progenitor cells as biomarker of vascular reparation? Insights in Biomed 2017;2:4-7.

16. Shan Y, Lin J, Xu P, Zeng M, Lin H, Yan H. The combined effect of hypertension and type 2 diabetes mellitus on aortic stiffness and endothelial dysfunction: an integrated study with high-resolution MRI. Magn Reson Imaging 2014;32:211-6.

17. Jamwal S, Sharma S. Vascular endothelium dysfunction: a conservative target in metabolic disorders. Inflamm Res 2018;67:391-405.

18. Triches CB, Mayer S, Quinto BMR, Batista MC, Zanella MT. Association of endothelial dysfunction with cardiovascular risk factors and new-onset diabetes mellitus in patients with hypertension. J Clin Hypertens (Greenwich) 2018; doi: 10.1111/jch.13269.

19. Berezin AE. Endothelial progenitor cells dysfunction and impaired tissue reparation: the missed link in diabetes mellitus development. Diabetes Metab Syndr 2017;11:215-20.

20. Asahara T, Murohara T, Sullivan A, Silver M, van der Zee R, Li T, Witzenbichler B, Schatteman G, Isner JM. Isolation of putative progenitor endothelial cells for angiogenesis. Science 1997;275:964-6.

21. Asahara T. Endothelial progenitor cells for vascular medicine. Yakugaku Zasshi 2007;127:841-5. [in Japanese]

22. Patel J, Donovan P, Khosrotehrani K. Concise review: functional definition of endothelial progenitor cells: a molecular perspective. Stem Cells Transl Med 2016;5:1302-6.

23. Yi C, Xia W, Zheng Y, Zhang L, Shu M, Liang J, Han Y, Guo S. Transplantation of endothelial progenitor cells transferred by vascular endothelial growth factor gene for vascular regeneration of ischemic flaps. J Surg Res 2006;135:100-6. 
24. Asahara T, Masuda H, Takahashi T, Kalka C, Pastore C, Silver M, Kearne M, Magner M, Isner JM. Bone marrow origin of endothelial progenitor cells responsible for postnatal vasculogenesis in physiological and pathological neovascularization. Circ Res 1999;85:221-8.

25. Murohara T. Angiogenesis and vasculogenesis for therapeutic neovascularization. Nagoya J Med Sci 2003;66:1-7.

26. Charlene A. McQueen, editor-in-chief. Comprehensive toxicology. Amsterdam: Elsevier Science; 2018. p. 130-82.

27. Böldicke T, Tesar M, Griesel C, Rohde M, Gröne HJ, Waltenberger J, Kollet O, Lapidot T, Yayon A, Weich H. Anti-VEGFR-2 scFvs for cell isolation. Single-chain antibodies recognizing the human vascular endothelial growth factor receptor-2 (VEGFR-2/flk-1) on the surface of primary endothelial cells and preselected CD34+ cells from cord blood. Stem Cells 2001;19:24-36.

28. Ferreras C, Cole CL, Urban K, Jayson GC, Avizienyte E. Segregation of late outgrowth endothelial cells into functional endothelial CD34- and progenitor-like CD34+ cell populations. Angiogenesis 2015;18:47-68.

29. Popa ER, Harmsen MC, Tio RA, van der Strate BW, Brouwer LA, Schipper M, Koerts J, De Jongste MJ, Hazenberg A, Hendriks M, van Luyn MJ. Circulating CD34+ progenitor cells modulate host angiogenesis and inflammation in vivo. J Mol Cell Cardiol 2006;41:86-96.

30. Xu QB. Endothelial progenitor cells in angiogenesis. Sheng Li Xue Bao 2005;57:1-6.

31. Hristov M, Erl W, Weber PC. Endothelial progenitor cells: mobilization, differentiation, and homing. Arterioscler Thromb Vasc Biol 2003;23:1185-9.

32. Iwaguro H, Yamaguchi J, Kalka C, Murasawa S, Masuda H, Hayashi S, Silver M, Li T, Isner JM, Asahara T. Endothelial progenitor cell vascular endothelial growth factor gene transfer for vascular regeneration. Circulation 2002;105:732-8.

33. Yamaguchi J, Kusano KF, Masuo O, Kawamoto A, Silver M, Murasawa S, Bosch-Marce M, Masuda H, Losordo DW, Isner JM, Asahara T. Stromal cell-derived factor-1 effects on ex vivo expanded endothelial progenitor cell recruitment for ischemic neovascularization. Circulation 2003; 107:1322-8.

34. Hiasa K, Ishibashi M, Ohtani K, Inoue S, Zhao Q, Kitamoto S, Sata M, Ichiki T, Takeshita A, Egashira K. Gene transfer of stromal cellderived factor-1alpha enhances ischemic vasculogenesis and angiogenesis via vascular endothelial growth factor/endothelial nitric oxide synthase-related pathway: next-generation chemokine therapy for therapeutic neovascularization. Circulation 2004;109:2454-61.

35. Pasut A, Chang NC, Gurriaran-Rodriguez U, Faulkes S, Yin H, Lacaria M, Ming H, Rudnicki MA. Notch signaling rescues loss of satellite cells lacking Pax7 and promotes brown adipogenic differentiation. Cell Rep 2016;16:333-43.

36. Kachamakova-Trojanowska N, Bukowska-Strakova K, Zukowska M, Dulak J, Jozkowicz A. The real face of endothelial progenitor cells - circulating angiogenic cells as endothelial prognostic marker? Pharmacol Rep 2015;67:793-802.

37. Fang S, Wei J, Pentinmikko N, Leinonen H, Salven P. Generation of functional blood vessels from a single c-kit+ adult vascular endothelial stem cell. PLoS Biol 2012;10:e1001407.

38. Ingram DA, Mead LE, Moore DB, Woodard W, Fenoglio A, Yoder MC. Vessel wall-derived endothelial cells rapidly proliferate because they contain a complete hierarchy of endothelial progenitor cells. Blood 2005;105:2783-6.

39. Yoder MC. Is endothelium the origin of endothelial progenitor cells? Arterioscler Thromb Vasc Biol 2010;30:1094-103.

40. Berezin AE. Biomarkers for cardiovascular risk in patients with diabetes. Heart 2016;102:1939-41.

41. Qu K, Wang Z, Lin XL, Zhang K, He XL, Zhang H. MicroRNAs: key regulators of endothelial progenitor cell functions. Clin Chim Acta 2015;448:65-73.

42. Berezin AE, Kremzer AA, Berezina TA, Martovitskaya YV. The pattern of circulating microparticles in patients with diabetes mellitus with asymptomatic atherosclerosis. Acta Clin Belg 2016;71:38-45.

43. Berezin AE, Kremzer AA, Berezina TA, Martovitskaya YV, Gronenko EA. Data regarding association between serum osteoprotegerin level, numerous of circulating endothelial-derived and mononuclear-derived progenitor cells in patients with metabolic syndrome. Data Brief 2016;8:717-22.

44. Berezin AE, Samura TA, Kremzer AA, Berezina TA, Martovitskaya YV, Gromenko EA. An association of serum vistafin level and number of circulating endothelial progenitor cells in type 2 diabetes mellitus patients. Diabetes Metab Syndr 2016;10:205-12.

45. Berezin AE, Kremzer AA. Relationship between circulating endothelial progenitor cells and insulin resistance in non-diabetic patients with ischemic chronic heart failure. Diabetes Metab Syndr 2014;8:138-44.

46. Berezin AE, Kremzer AA, Samura TA, Berezina TA, Kruzliak P. Impaired immune phenotype of circulating endothelial-derived microparticles in patients with metabolic syndrome and diabetes mellitus. J Endocrinol Invest 2015;38:865-74.

47. Bakogiannis C, Tousoulis D, Androulakis E, Briasoulis A, Papageorgiou N, Vogiatzi G, Kampoli AM, Charakida M, Siasos G, Latsios G, Antoniades C, Stefanadis C. Circulating endothelial progenitor cells as biomarkers for prediction of cardiovascular outcomes. Curr Med Chem 2012;19:2597-604.

48. Berezin AE, Kremzer AA. Circulating endothelial progenitor cells as markers for severity of ischemic chronic heart failure. J Card Fail 2014;20:438-47.

49. Berezin AE, Kremzer AA, Samura TA, Berezina TA, Martovitskaya YV. Serum uric Acid predicts declining of circulating proangiogenic mononuclear progenitor cells in chronic heart failure patients. J Cardiovasc Thorac Res 2014;6:153-62.

50. Mohandas R, Segal MS. Endothelial progenitor cells and endothelial vesicles - what is the significance for patients with chronic kidney disease? Blood Purif 2010;29:158-62.

51. Fadini GP, Sartore S, Baesso I, Lenzi M, Agostini C, Tiengo A, Avogaro A. Endothelial progenitor cells and the diabetic paradox. Diabetes Care 2006;29:714-6.

52. Tan K, Lessieur E, Cutler A, Nerone P, Vasanji A, Asosingh K, Erzurum S, Anand-Apte B. Impaired function of circulating CD34(+) CD45(-) cells in patients with proliferative diabetic retinopathy. Exp Eye Res 2010;91:229-37.

53. Lombardo MF, Iacopino P, Cuzzola M, Spiniello E, Garreffa C, Ferrelli F, Coppola A, Saccardi R, Piaggesi A, Piro R, Mannino D, Grossi G, Lauro D, Irrera G. Type 2 diabetes mellitus impairs the maturation of endothelial progenitor cells and increases the number of 
circulating endothelial cells in peripheral blood. Cytometry A 2012;81:856-64.

54. Fadini GP, Sartore S, Agostini C, Avogaro A. Significance of endothelial progenitor cells in subjects with diabetes. Diabetes Care 2007;30:1305-13.

55. Ruszkowska-Ciastek B, Sokup A, Leszcz M, Drela E, Stankowska K, Boinska J, Haor B, Ślusarz R, Lisewska B, Gadomska G, Kubica J, Rość D. The number of circulating endothelial progenitor cells in healthy individuals--effect of some anthropometric and environmental factors (a pilot study). Adv Med Sci 2015;60:58-63.

56. Kulwas A, Drela E, Jundziłł W, Góralczyk B, Ruszkowska-Ciastek B, Rość D. Circulating endothelial progenitor cells and angiogenic factors in diabetes complicated diabetic foot and without foot complications. J Diabetes Complications 2015;29:686-90.

57. Nowak WN, Borys S, Kusińska K, Bukowska-Strakova K, Witek P, Koblik T, Józkowicz A, Małecki MT, Dulak J. Number of circulating pro-angiogenic cells, growth factor and anti-oxidative gene profiles might be altered in type 2 diabetes with and without diabetic foot syndrome. J Diabetes Investig 2014;5:99-107.

58. Drela E, Stankowska K, Kulwas A, Rość D. Endothelial progenitor cells in diabetic foot syndrome. Adv Clin Exp Med 2012;21:249-54.

59. Berezin A. Epigenetics in heart failure phenotypes. BBA Clin 2016;6:31-7.

60. Chong AY, Lip GYH, Freestone B, Blann AD. Increased circulating endothelial cells in acute heart failure: comparison with von Willebrand factor and soluble E-selectin. Eur J Heart Fail 2006;8:167-72.

61. Boos CJ, Lip GYH, Blann AD. Circulating endothelial cells in cardiovascular disease. J Am Coll Cardiol 2006;48:1538-47.

62. Dignat-George F, Sampol J. Circulating endothelial cells in vascular disorders: new insights into an old concept. Eur J Haematol 2000;65:215-20.

63. Wang C, Li H, Fu P, Zhang S, Xiu R. Serum C-reactive protein and circulating endothelial cells in patients with acute myocardial infarction. Clin Hemorheol Microcirc 2005;32:287-96.

64. Makin AJ, Blann AD, Chung NAY, Silverman SH, Lip GYH. Assessment of endothelial 1018 damage in atherosclerotic vascular disease by quantification of circulating endothelial cells. Relationship with von Willebrand factor and tissue factor. Eur Heart J 2004;25:371-6.

65. Mutin M, Canavy I, Blann A, Bory M, Sampol J, Dignat-George F. Direct evidence of endothelial injury in acute myocardial infarction and unstable angina by demonstration of circulating endothelial cells. Blood 1999;93:2951-8.

66. Grochot-Przeczek A, Kotlinowski J, Kozakowska M, Starowicz K, Jagodzinska J, Stachurska A, et al. Heme oxygenase-1 is required for angiogenic function of bone marrow-derived progenitor cells: role in therapeutic revascularization. Antioxid Redox Signal 2014:20:1677-92.

67. Yoon C-H, Hur J, Park K-W, Kim J-H, Lee C-S, Oh I-Y, Kim TY, Cho HJ, Kang HJ, Chae IH, Yang HK, Oh BH, Park YB, Kim HS. Synergistic neovascularization by mixed transplantation of early endothelial progenitor cells and late outgrowth endothelial cells: the role of angiogenic cytokines and matrix metalloproteinases. Circulation 2005;112:1618-27.

68. Oh IY, Yoon CH, Hur J, Kim JH, Kim TY, Lee CS, Park KW, Chae IH, Oh BH, Park YB, Kim HS. Involvement of E-selectin in recruitment of endothelial progenitor cells and angiogenesis in ischemic muscle. Blood 2007;110:3891-9.

69. Yoon CH, Hur J, Oh IY, Park KW, Kim TY, Shin JH, Kim JH, Lee CS, Chung JK, Park YB, Kim HS. Intercellular adhesion molecule-1 is upregulated in ischemic muscle, which mediates trafficking of endothelial progenitor cells. Arterioscler Thromb Vasc Biol 2006; 26:1066-72.

70. Ling L, Shen Y, Wang K, Jiang C, Fang C, Ferro A, Kang L, Xu B. Worse clinical outcomes in acute myocardial infarction patients with type 2 diabetes mellitus: relevance to impaired endothelial progenitor cells mobilization. PLoS One 2012;7:e50739.

71. Hoenig MR, Bianchi C, Sellke FW. Hypoxia inducible factor-1 alpha, endothelial progenitor cells, monocytes, cardiovascular risk, wound healing, cobalt and hydralazine: a unifying hypothesis. Curr Drug Targets 2008;9:422-35.

72. Hexum MK, Tian X, Kaufman DS. In vivo evaluation of putative hematopoietic stem cells derived from human pluripotent stem cells. Methods Mol Biol 2011;767:433-47.

73. Li B, Cohen A, Hudson TE, Motlagh D, Amrani DL, Duffield JS. Mobilized human hematopoietic stem/progenitor cells promote kidney repair after ischemia/reperfusion injury. Circulation 2010;121:2211-20.

74. Kang L, Chen Q, Wang L, Gao L, Meng K, Chen J, Ferro A, Xu B. Decreased mobilization of endothelial progenitor cells contributes to impaired neovascularization in diabetes. Clin Exp Pharmacol Physiol 2009;36:e47-56.

75. Li Y, Alatan G, Ge Z, Liu D. Effects of benazepril on functional activity of endothelial progenitor cells from hypertension patients. Clin Exp Hypertens 2014;36:545-9.

76. Berezin AE, Kremzer AA, Martovitskaya YV, Samura TA. The effect of angiotensin-2 receptor blocker valsartan on circulating level of endothelial progenitor cells in diabetic patients with asymptomatic coronary artery disease. Diabetes Metab Syndr 2015;9:305-9.

77. Raptis AE, Markakis KP, Mazioti MC, Ikonomidis I, Maratou EP, Vlahakos DV, Kotsifaki EE, Voumvourakis AN, Tsirogianni AG, Lambadiari VA, Lekakis JP, Raptis SA, Dimitriadis GD. Effect of aliskiren on circulating endothelial progenitor cells and vascular function in patients with type 2 diabetes and essential hypertension. Am J Hypertens 2015;28:22-9.

78. Suzuki R, Fukuda N, Katakawa M, Tsunemi A, Tahira Y, Matsumoto T, Ueno T, Soma M. Effects of an angiotensin II receptor blocker on the impaired function of endothelial progenitor cells in patients with essential hypertension. Am J Hypertens 2014;27:695-701.

79. Burger D, Touyz RM. Cellular biomarkers of endothelial health: microparticles, endothelial progenitor cells, and circulating endothelial cells. J Am Soc Hypertens 2012;6:85-99.

80. Mehta JL, Szwedo J. Circulating endothelial progenitor cells, microparticles and vascular disease. J Hypertens 2010;28:1611-3.

81. Lee CW, Huang PH, Huang SS, Leu HB, Huang CC, Wu TC, Chen JW, Lin SJ. Decreased circulating endothelial progenitor cell levels and function in essential hypertensive patients with electrocardiographic left ventricular hypertrophy. Hypertens Res 2011; 34:999-1003.

82. Lineen JR, Kuliszewski M, Dacouris N, Liao C, Rudenko D, Deva DP, Goldstein M, Leong-Poi H, Wald R, Yan AT, Yuen DA. Early 
outgrowth pro-angiogenic cell number and function do not correlate with left ventricular structure and function in conventional hemodialysis patients: a cross-sectional study. Can J Kidney Health Dis 2015;2:25.

83. Heimrath J, Paprocka M, Czekanski A, Ledwozyw A, Kantor A, Dus D. Pregnancy-induced hypertension is accompanied by decreased number of circulating endothelial cells and circulating endothelial progenitor cells. Arch Immunol Ther Exp (Warsz) 2014;62:353-6.

84. Grundmann M, Woywodt A, Kirsch T, Hollwitz B, Oehler K, Erdbruegger U, Haller H, Haubitz M.. Circulating endothelial cells: a marker of vascular damage in patients with preeclampsia. Am J Obstet Gynecol 2008;198:e1-5.

85. Hunting CB, Noort WA, Zwaginga JJ. Circulating endothelial progenitor cells reflect the state of endothelium: vascular injury, repair and neovasculatization. Vox Sang 2005;88:1-9.

86. Eirin A, Zhu XY, Ebrahimi B, Krier JD, Riester SM, van Wijnen AJ, Lerman A, Lerman LO. Intrarenal delivery of mesenchymal stem cells and endothelial progenitor cells attenuates hypertensive cardiomyopathy in experimental renovascular hypertension. Cell Transplant 2015;24:2041-53.

87. Marketou ME, Kalyva A, Parthenakis FI, Pontikoglou C, Maragkoudakis S, Kontaraki JE, Chlouverakis G, Zacharis EA, Patrianakos A, Papadaki HA, Vardas PE. Circulating endothelial progenitor cells in hypertensive patients with increased arterial stiffness. J Clin Hypertens (Greenwich) 2014;16:295-300.

88. Skrzypkowska MW, Ryba-Stanisławowska ME, Słomiński B, Gutknecht PG, Siebert J, Myśliwska JM. Association of circulating progenitor cells with angiotensin II in newly diagnosed hypertensive patients. J Hum Hypertens 2017;32:46-53.

89. Skrzypkowska M, Słomiński B, Ryba-Stanisławowska M, Gutknecht P, Siebert J. Circulating CD34+ and CD34+VEGFR2+ progenitor cells are associated with KLOTHO KL-VS polymorphism. Microvasc Res 2018; doi: 10.1016/j.mvr.2018.03.014.

90. King TF, McDermott JH. Endothelial progenitor cells and cardiovascular disease. J Stem Cells 2014;9:93-106.

91. Berezin AE, Kremzer AA, Martovitskaya YV, Samura TA, Berezina TA, Zulli A, Klimas J, Kruzliak P. The utility of biomarker risk prediction score in patients with chronic heart failure. Int J Clin Exp Med 2015;8:18255-64.

92. Berezin AE, Kremzer AA. Analysis of various subsets of circulating mononuclear cells in asymptomatic coronary artery disease. J Clin Med 2013;2:32-44.

93. Giles TD, Sander GE. Endothelial progenitor cells as a biomarker for transitional phenotypes in hypertension. J Clin Hypertens (Greenwich) 2015;17:580-1. 